\title{
Relationship between HCV infection and Insulin resistance in non-obese non- diabetic patients
}

\author{
Mostafa K.Mohamed ${ }^{1}$,Gamal Esmat ${ }^{2}$, Mohamed Said ${ }^{2}$, Mohamed Abdel Hamid ${ }^{3}$, \\ Mohamed Hassany ${ }^{4}$,Mohamad A.Hassanein ${ }^{4}$, Kamal A.El- Atrebi ${ }^{4}$ Helmy El Gazzar ${ }^{5}$, \\ M S. Omar ${ }^{6}$.
}

1-Department of Community, Environmental and Occupational Medicine, Faculty of Medicine, Ain

Shams University.

2-Department of Tropical Medicine, Cairo University.

3-Viral Hepatitis Research Laboratory, National Hepatology and Tropical Medicine Research Institute 4- Department of Tropical Medicine, National Hepatology and Tropical Medicine Research Institute.

5-Department of Clinical pathology, Hearing and Speech Institute, Egypt.

6- Department of Clinical pathology, Faculty of Medicine, Bani Sewif University.

\begin{abstract}
Background: Hepatitis $\mathrm{C}$ is a major cause of liver-related morbidity and mortality and represents a major public health problem in Egypt and worldwide. There is growing evidence as regard to the association between hepatitis $\mathrm{C}$ virus (HCV) infection and type 2 diabetes mellitus. However, the mutual link and related virological implication have not been fully clarified. Insulin resistance (IR) plays a primary role in the development of type $2 \mathrm{DM}$. This is supported by the results of prospective longitudinal studies showing that IR is the best predictor of the development of type $2 \mathrm{DM}$, preceding its onset by 10-20 years.
\end{abstract}

Aim: To assess the correlation between HCV morbidity and Insulin resistance (IR) detected by HOMA test in none diabetic none obese HCV patients

Materials \& Method: The study participants were subcategorized into two groups, Group (I): included 867 healthy subjects (negative HCV RNA) as a control group. Group (II): included 277 patients with chronic HCV as a study group. The 2 groups were subjected to thorough history taking, full clinical examination, Anthropometric study,ultrasonographic examination and laboratory investigations including liver functions, viral markers, and qualitative PCR for HCV RNA ,lipid profile, glucose profile and HOMA test .

Results: This study revealed higher insulin resistance in the HCV study group than the control group.

Key words: HCV-Insulin resistance,HOMA test

\section{Introduction:}

The incidence of noncommunicable diseases (NCDs) such as cardiovascular disease (CVD), diabetes, cancer, renal, genetic and respiratory diseases is rising significantly in the Eastern Mediterranean Region .In Egypt noncommunicable diseases account for about $42 \%$ of the total deaths while CVD accounts for about $22 \%$ of deaths (WHO, 2004). Hepatitis $C$ is a major cause of liver-related morbidity and mortality and represents a major public health problem in Egypt and worldwide
(Alberti and Benvegnu, 2003) and there is a large underlying reservoir of $\mathrm{HCV}$-caused liver disease (Strickland et al., 2002). The countries of the Eastern Mediterranean Region are, therefore, suffering from a double burden of both communicable and noncommunicable diseases (WHO, 2004). The link between communicable and noncommunicable diseases could exist. In some studies, chronic infections have been found to be associated with atherosclerosis (Leinonen and Saikku, 2002). There is growing evidence as regard to the association between hepatitis $\mathrm{C}$ virus 
(HCV) infection and type 2 diabetes mellitus. However, the mutual link and related virological implication have not been fully clarified (Jee-Fu et al,2007).Insulin resistance (IR) plays a primary role in the development of type 2 DM. This is supported by the results of prospective longitudinal studies showing that IR is the best predictor of the development of type 2 DM, preceding its onset by 10-20 years. (IR) is widely regarded as an important component of type 2 DM. Some authors have used the term 'insulin sensitivity', which is the reciprocal of insulin resistance, because the term 'normal insulin sensitivity' is more meaningful than 'normal insulin resistance' (Haffner, 1997).

IR describes a state where there is reduced biological effect for any given concentration of insulin (Hunter and Garvey, 1998). Insulin resistance is an independent risk factor for cardiovascular disease and Type 2 DM. Hypertension, dyslipidaemia and obesity are often found in association with IR. However the presence of these conditions cannot be used as evidence of the coexistence of IR (Opara and Levine, 1997). Although Himsworth and others had described insulinresistant diabetic patients in the late 1930s based on dosages required, Yalow and Berson (1968) (who described the insulin immunoassay) showed that insulin concentrations were higher in those with Type 2 DM. This was the first description of IR based on plasma measurements of the hormone.

IR can be physiological, as occurs in pregnancy and in puberty, or pathological. It may occur as a primary phenomenon, be secondary to other disorders, or may arise as a result of specific defects such as insulin receptor mutations. The commonest described state of IR is the metabolic syndrome (Syndrome X, Reaven's syndrome, Type 2 $\mathrm{DM}$, the IR syndrome) which is characterized by the combination of IR, hyperglycaemia, hypertension, dyslipidaemia (low HDL, small dense LDL, high triglycerides), hyperuricaemia and obesity (Haffner and Miettinen , 1997).

\section{Methods for assessing insulin resistance:}

\section{I-Insulin dose}

$\underline{\text { II-Insulin concentration in plasma }}$

III-Quantitative estimates of insulin
$\underline{\text { resistance }}$

\section{1-MODELS}

a) Homeostasis Assessment Model (HOMA)

b) Continuous Infusion of Glucose with Model Assessment (CIGMA)

c) Quantitative insulin-sensitivity check index (QUICKI)

d) McCauley index

e) HOMA-AD

f) Fasting insulin glucose ratio $(F I G)$

g) Frequently sampled intravenous glucose tolerance test (FSIGTT)

\section{2-Clamps}

I) Euglycaemic clamp
II) Hyperglycemic clamp

3-Insulin infusion sensitivity tests

I) Insulin sensitivity test (IST)

II) Short insulin tolerance test (ITT)

\section{4-Oral glucose tolerance test}

The Homeostasis Assessment Model (HOMA)is a mathematical model, which allows values for insulin sensitivity and $\beta$-cell function (expressed as a percentage of normal) to be obtained if simultaneous fasting plasma glucose and fasting insulin are known (Matthews et al., 1985). Since insulin secretion is pulsatile, the optimal sample should be the mean of three results at 5-min intervals $(0,5$, and 10-min samples). However, many researchers have used single basal samples for epidemiological studies. HOMA has proved to be a good method for assessing insulin resistance in groups of patients over long periods of time because the sampling is simple, and the result is available without complex computing as soon as fasting glucose and insulin values are available (Emoto et al., 1999). Estimates of insulin resistance from HOMA correlate well with estimates from the euglycaemic clamp (Bonora et al., 2000). In contrast to other methods, HOMA gives an estimate of basal insulin resistance, whereas all other tests provide estimates of stimulated insulin resistance.

HOMA produces a formula for insulin 
resistance $\left(R_{\mathrm{HOMA}}\right)$ calculated as:

$\frac{\text { Fasting glucose (mmol/l) X Fasting insulin }(\mu \mathrm{IU} / \mathrm{ml})}{22.5}$

In addition, HOMA was used to calculate beta-cell function as percentage of normal $(\%)$ using the formula:

$20 \mathrm{X}$ Fasting insulin $(\mu \mathrm{IU} / \mathrm{ml})$

Fasting glucose (mmol/l) - 3.5

The cutoff value for insulin resistance in HOMA is a matter of debate, (Nakai et al., 2002) (Taniguchi et al., 2000) defined the value $>2.5$ as an insulin-resistant state based on the HOMA-IR value. While (Sihoon Lee et al., 2006), in their study, found that the cutoff point for defining insulin resistance is a HOMA-IR=3.04. Bonora et al., 1998 defined 2.77 as cutoff value for insulin resistance in HOMA score.

Relationship between $\mathrm{HCV}, \mathrm{DM}$ and insulin resistance in various stages of disease:

\section{1- HCV Chronic hepatitis and insulin} resistance:

An increased prevalence of diabetes among HCV-infected patients with chronic hepatitis compared with either subjects with other chronic liver disease or the general population has been consistently reported( $\ddot{O}_{z y l i l k a n}$ and Arslan, 1996) (Mangia et al., 1998). The prevalence not only of diabetes but also the impaired fasting glucose (IFG) in a large cohort of HCV-infected patients, was also found (Mason et al., 1999).

\section{2-HCV liver cirrhosis and insulin resistance:}

When HCV-infected patients with cirrhosis are evaluated, the prevalence of type 2 diabetes is higher than reported in patients with chronic hepatitis, and it ranges from 19.6 to $50 \%$ (Garrido et al.,2001) (Parolin et al.,2004).(Thuluvath and John, 2003) found no significant difference between cirrhotic patients with or without HCV infection. Therefore, it seems that the presence of advanced liver disease is an even stronger diabetogenic factor than $\mathrm{HCV}$ infection itself. In other words, diabetes associated with $\mathrm{HCV}$ infection is less of a determinate than the effect of hepatic cirrhosis on glucose metabolism (Zein et al., 2000). Also, (Lecube et al., 2004) did not observe differences between cirrhotic patients with or without $\mathrm{HCV}$ infection. These findings suggest that the genuine connection between $\mathrm{HCV}$ infection and diabetes is initiated at the early stages of hepatic disease. They detected a five foldhigher prevalence of diabetes than that found among anti-HCV-negative patients (24 vs. $5 \%$ ).

\section{3-HCV infection as a risk factor for post-} transplant diabetes:

Post-transplantation diabetes mellitus (PTDM) is a common medical condition arising during the follow-up of renal and liver transplant recipients, which has increased in incidence over the last decade (Cosio et al., 2001). A number of risk factors related to the recipient, the immunosuppressive agents used to prevent and treat rejection, and donor source have been described as independent risk factors for the development of PTDM(Kasiske et al., 2003). The prevalence of PTDM in HCVinfected liver transplantation recipients ranges from 40 to $64 \%$, significantly higher than the prevalence reported in transplanted patients for other causes of liver failure (Bigam et al., 2000). In addition, HCV has been found to be an independent risk factor for diabetes development after transplantation. Furthermore, (Baid et al., 2001) reported a close temporal relationship between the recurrence of $\mathrm{HCV}$ hepatitis in the allograft and the onset of PTDM in approximately half of the HCV-positive patients with PTDM.HCV infection may reach an incidence of $50 \%$ in patients with end-stage renal disease, and it has also been identified as an independent risk factor for predicting the development of PTDM after renal transplantation (Yildiz et al., 2002).

All these data reinforce the hypothesis that $\mathrm{HCV}$ is the cause rather than the consequence of diabetes. In addition, the link between $\mathrm{HCV}$ and diabetes may contribute substantially to the detrimental role of $\mathrm{HCV}$ on patient and graft survival after liver transplantation and/or renal transplantation (Abbott et al., 2004).

\section{Patients and methods:}

It is a prospective study for 1144 participants recruited through a cohort from a village in Monoufia governorate in Delta region of Egypt. The study protocol was approved by the Egyptian Ministry of Health and Population Institutional Review Board and a 
local ethics committee set up for hepatitis studies in Egypt.The study participants were subcategorized into two groups:

Group (I): included 867 healthy subjects (negative HCV RNA) as a control group.

Group (II): included 277 patients with chronic $\mathrm{HCV}$ as a study group.

Inclusion criteria were adult patients $>18$ years old,positive serology for $\mathrm{HCV}$ and $\mathrm{HCV}$ viremia,none diabetic (negative history and fasting blood sugar level $<126 \mathrm{mg} / \mathrm{dl}$ ) and none obese (BMI < 30).

Exclusion criteria were negative $\mathrm{HCV}$ viremia,positive $\mathrm{HBsAg}$,diabetic patients (known diabetic or FBS $>126 \mathrm{mg} / \mathrm{dl}$ ) and obese patients $(\mathrm{BMI}>30)$.

All participating subjects, after a written consent, were subjected to the following Icareful history taking, Including age, present and past occupation and residence ,history of drug or alcohol intake ,history of schistosomiasis and previous parenteral treatment for it , history of blood transfusion ,dental procedure and operations. Any associated disease as diabetes mellitus or hypertension and any present complaint IIThorough clinical examination.III. Anthropometric study was done for all studied patients focusing on evaluation of body mass index (BMI) which is equal to weight/height 2 (in $\mathrm{kg} / \mathrm{m} 2$ ); with BMI ranging between 19 to $25 \mathrm{~kg} / \mathrm{m} 2$ refer to normal average. BMI of 30 or more is most commonly used as threshold for obesity while BMI between 25 and 30 are suggesting overweight (CDC, 2009).IV. Laboratory assays including:

a) Glucose profile(Fasting glucose- Specific insulin assay- C-peptide)

b) Liver function tests(AST,ALT,Bilirubin,Albumin,ALP,INR)

c) Viral markers( $\mathrm{HBs} \mathrm{Ag}, \mathrm{HBc} \mathrm{Ab}$ and $\mathrm{HCV}$ $\mathrm{Ab})$

d)Qualitative HCV RNA by PCR.

e) Homeostasis model assessment (HOMA) score estimation

\section{Laboratory assays:}

Blood sampling, about $10 \mathrm{ml}$ venous blood were obtained from each individual, $2 \mathrm{ml}$ were collected in a tube containing dipotassium EDETA as an anticoagulant for qualitative detection of HCV RNA , another $1.8 \mathrm{ml}$ were collected in a tube containing $0.2 \mathrm{ml}$ sodium citrate for PT detection. The remaining $6 \mathrm{ml}$ were collected in a plain tube, allowed to clot and centrifuged to get serum. Blood glucose and liver function tests were done immediately after centrifugation, the remaining serum was stored at $-20 \mathrm{oC}$ as aliquots for demonstration of insulin level, $\mathrm{C}$ peptide, and viral markers.

\section{The laboratory evaluations include:}

A-Glucose profile: fasting glucose level was measured by enzymatic colorimetric method using kit provided from Human, Germany. Insulin level and C-peptide were demonstrated in serum by using semi-automated ELISA system (TC,96, USA), kit provided from DRG International,USA .The absorbance values were read using ELISA reader at wave length $450+10 \mathrm{~nm}$ for both insulin and Cpeptide(Chieregatti, 1999).

The concentrations were calculated using computer software capable of generating a four parameters algorithm.

*Calculation of insulin resistance according to HOMA score (homeostasis model assessment), (Matthews et al., 1985).using the following:

HOMA insulin resistance score $=$

Fasting glucose $(\mathrm{mmol} / \mathrm{l} \mathrm{x}$ insulin $(U \mathrm{u} / \mathrm{ml})$

$$
22.5
$$

B-Liver function tests and lipid profile were measured by semi automated chemical analyzer (Chem 7 plus,Germany), using kit provided from ELI Tech, France,for AST,ALT and ALP and from Human, Germany for albumin, bilirubin, PT and serum lipid.

\section{C-Viral laboratory assessment:}

1.Serological tests for $\mathrm{HBsAg}, \mathrm{HBcAb}$ and $\mathrm{HCVAb}$ by ELISA technique(Chieregatti,1999), using kit provided from EIA gen, Adaltis, Italy. The color intensity was measured at $450 \mathrm{~nm}$ with reference filter 620- $630 \mathrm{~nm}$. The concentrations have been calculated automatically using 4 parameter logistics computer software.

2. Qualitative detection of HCV RNA by the method of Reverse Transcriptase PCR, this falls into four main steps:

*HCV RNA extraction using the QIAmp Viral RNA kit, Germany, then this is followed by cDNA synthesis within 3 hours or stored at -80 OC for up to one month with no more than one freeze-thraw.

*Reverse transcription of extracted HCV RNA into complementary DNA(c- DNA) and first 
round PCR amplification using primers for $\mathrm{HCV}$, the sequences of the primers were as follows:

\section{P1 5'AACTACTGTCTTCACGCAGAA3' \\ P2 5'GGTGCACGGTCTACGACCTC3'.}

The amplification procedure was performed by thermal cycler apparatus (PTC-200, USA) programmed as follows; $42^{\circ} \mathrm{C}$ for $30 \mathrm{~min}$; $95^{\circ} \mathrm{C}$ for $5 \mathrm{~min}$ followed by 30 cycles $\left(94^{\circ} \mathrm{C}\right.$ for $1 \mathrm{~min}, 55^{\circ} \mathrm{C}$ for $1 \mathrm{~min}$ and $72^{\circ} \mathrm{C}$ for 1 minute) and finally $72^{\circ} \mathrm{C}$ for $5 \mathrm{~min}$.

*Second round PCR amplification was performed in a thermocycler programmed as follows; $95^{\circ} \mathrm{C}$ for $5 \mathrm{~min}$ followed by 30 cycles $\left(94^{\circ} \mathrm{C}\right.$ for $1 \mathrm{~min}, 55^{\circ} \mathrm{C}$ for $1 \mathrm{~min}$ and $72^{\circ} \mathrm{C}$ for 1 minute) and finally $72^{\circ} \mathrm{C}$ for $5 \mathrm{~min}$, using primers with sequences as follows:

P3 5'GTGCAGCCTCCAGGACCC3'

P4 5'ACTCGGCTAGCAGTCTCGCG3'.

*Detection of the amplified fragments by loading the amplified products on $2.5 \%$ agarose gel and visualized using UV transilluminator. Band sizes were compared to a 50-bp DNA ladder. A fragment of $171 \mathrm{bp}$ length was identified as a positive sample.

\section{Statistical analysis:}

We used following software in our research statistics SPSS version 16 and Microsoft excel with analyze-it add in.Description of qualitative variables by frequency and percentage.description of quantitative variables in the form of mean and standard deviation (mean $\pm \mathrm{SD}$ ). Chi-square $(\mathrm{x} 2)$ test was used for comparison of qualitative variables with each other.Comparison between quantitative variables was carried by using student t-test of two independent samples. One way ANOVA test (analysis of variance) was used instead of t-test for comparison of more than two quantitative groups.Kruskal wallis ANOVA test used for categorical data.Significance level (p) was expressed as following:P value $>0.05$ is insignificant, $P$ value $<0.05$ is significant and $P$ value $<0.001$ is highly significant.Correlation studies were done using person test for quantitative data and spearman test for categorical data.

\section{Results}

\begin{tabular}{|l|c|c|c|c|l|}
\hline & \multicolumn{2}{|c|}{ Group I } & \multicolumn{2}{c|}{ Group II } & \\
\hline & Mean & SD & Mean & SD & P Value \\
\hline Weight(Kg) & $\mathbf{6 5 . 9 6}$ & $\mathbf{1 0 . 4 0}$ & $\mathbf{6 6 . 9 1}$ & $\mathbf{1 0 . 0 8}$ & $>\mathbf{0 . 0 5}$ \\
\hline Height(cm) & $\mathbf{1 6 2 . 1 9}$ & $\mathbf{8 . 8 8}$ & $\mathbf{1 6 4 . 3 5}$ & $\mathbf{8 . 7 5}$ & $<\mathbf{0 . 0 5 ( S )}$ \\
\hline BMI & $\mathbf{2 5 . 0 2}$ & 2.97 & $\mathbf{2 4 . 7 6}$ & $\mathbf{2 . 8 5}$ & $>\mathbf{0 . 0 5}$ \\
\hline waist(cm) & $\mathbf{7 9 . 7 6}$ & $\mathbf{9 . 9 1}$ & $\mathbf{8 0 . 5 2}$ & $\mathbf{9 . 8 7}$ & $>\mathbf{0 . 0 5}$ \\
\hline
\end{tabular}

Table (1): Demographic features of the studied groups.

Age distribution of the studied patients was shown in table (1), there is significant difference between the mean ages in the 2 groups being higher in the study group than the control group, Group (I) included 387 males (45\%) and 480 females (55\%).Group (II) included 175 males (63\%) and 102 females $(37 \%)$.

Table (2) physical parameters of the studied groups.

\begin{tabular}{|c|c|c|c|c|c|}
\hline & \multicolumn{2}{|c|}{$\begin{array}{c}\text { Group I } \\
\text { (non infected } \mathrm{N}=\mathbf{8 6 7} \text { ) }\end{array}$} & $\begin{array}{c}\text { Group II } \\
\text { (chronic HCV N=277) }\end{array}$ & & $P$ value \\
\hline \multicolumn{6}{|l|}{ Age } \\
\hline mean $\pm \mathrm{SD}$ & 41.42 & 14.30 & 46.75 & 11.57 & $<0.05(\mathrm{~S})$ \\
\hline \multicolumn{6}{|l|}{ Sex } \\
\hline Males & 387.00 & $45 \%$ & 175.00 & $63 \%$ & \\
\hline Females & 480.00 & $55 \%$ & 102.00 & $37 \%$ & \\
\hline
\end{tabular}

Being important influencing factors, Table (2) shows no significant difference was found between both groups as regarding weight, waist circumference and BMI. 


\begin{tabular}{|c|c|c|c|c|c|}
\hline & \multicolumn{2}{|c|}{ Group I } & \multicolumn{2}{|c|}{ Group II } & \\
\hline & Mean & SD & Mean & SD & P Value \\
\hline AST (10-42 Iu/L) & 23.00 & 12.03 & 42.45 & 29.75 & $<0.05(\mathrm{~S})$ \\
\hline ALT (10-40 Iu/L) & 20.24 & 11.24 & 43.77 & 37.79 & $<0.05(\mathrm{~S})$ \\
\hline $\operatorname{ALB}(g / d l)-(3.5-5.0)$ & 3.95 & 0.41 & 3.85 & 0.48 & $<0.05(\mathrm{~S})$ \\
\hline $\begin{array}{l}\text { TBIL(mg/dl)-(0.1- } \\
\text { 1.0) }\end{array}$ & 0.65 & 0.36 & 0.82 & 0.42 & $<0.05(\mathrm{~S})$ \\
\hline $\begin{array}{l}\text { DBIL(mg/dl)-(0- } \\
0.2)\end{array}$ & 0.13 & 0.13 & 0.20 & 0.14 & $<0.05(\mathrm{~S})$ \\
\hline $\begin{array}{l}\text { IND BILI(mg/dl)- } \\
(0-0.8)\end{array}$ & 0.53 & 0.29 & 0.63 & 0.32 & $<0.05(\mathrm{~S})$ \\
\hline
\end{tabular}

Table (3): Liver functions of the studied groups.

Table (3) describes the liver functions of the studied groups, AST, ALT and total,direct and indirect bilirubin are significantly higher in the study group while albumin is significantly higher in the control group.

\begin{tabular}{|l|c|c|c|c|c|}
\hline & \multicolumn{2}{|c|}{ Group I } & \multicolumn{2}{c|}{ Group II } & \\
\hline & Mean & SD & Mean & SD & P Value \\
\hline F.B.S(mg/dl) & 80.63 & 9.36 & 81.62 & 9.26 & $>0.05$ \\
\hline Insulin $(\boldsymbol{\mu U} / \mathrm{ml})$ & 3.87 & $\mathbf{2 . 7 0}$ & 4.91 & 3.82 & $<\mathbf{0 . 0 5}(\mathbf{S})$ \\
\hline HOMA & $\mathbf{0 . 8 3}$ & $\mathbf{0 . 6 0}$ & 1.09 & $\mathbf{0 . 9 3}$ & $<\mathbf{0 . 0 5 ( S )}$ \\
\hline $\begin{array}{l}\text { C-Peptide(0.6-13.06 } \\
\text { ng/ml) }\end{array}$ & 1.29 & 1.28 & 1.18 & 1.20 & $>0.05$ \\
\hline
\end{tabular}

Table (4): Glucose profile of the studied groups.

As shown in table (4) Comparing HOMA-Score in both groups, the test was significantly higher in the study group than the control group, also serum insulin level being one of the HOMA equation components is significantly higher in the study group than in control group, meanwhile, the fasting blood sugar and c-peptide show no significant difference between both groups. 
Mostafa Mohamed ... et al

\begin{tabular}{|c|c|c|}
\hline & & Age in Years \\
\hline HOMA & Correlation Coefficient & -.049 \\
\hline & Sig. (2-tailed) & .479 \\
\hline & & AST \\
\hline & Correlation Coefficient & $.157^{*}$ \\
\hline & Sig. (2-tailed) & .023 \\
\hline & & ALT \\
\hline & Correlation Coefficient & $.212^{* *}$ \\
\hline & Sig. (2-tailed) & .002 \\
\hline & & ALB \\
\hline & Correlation Coefficient & -.117 \\
\hline & Sig. (2-tailed) & .092 \\
\hline & & T.BIL \\
\hline & Correlation Coefficient & .117 \\
\hline & Sig. (2-tailed) & .093 \\
\hline & & D.BIL \\
\hline & Correlation Coefficient & .045 \\
\hline & Sig. (2-tailed) & .516 \\
\hline & & BMI \\
\hline & $\begin{array}{c}\text { Correlation Coefficient } \\
\text { Sig. (2-tailed) }\end{array}$ & $\begin{array}{l}.359^{* *} \\
.000\end{array}$ \\
\hline
\end{tabular}

\section{Table (5): Nonparametric correlations (spearman correlation) between HOMA and other parameters}

Table(5) shows nonparametric correlations (spearman correlation) between HOMA index and age,AST,ALT, albumin, T.bilirubin, D.bilirubin and BMI, we observe high significant correlation between HOMA index and serum ALT level \& BMI , and significant correlation between HOMA Index and serum AST.These correlations were emphasized through the scattered plot curve (Fig.1) between HOMA versus BMI .

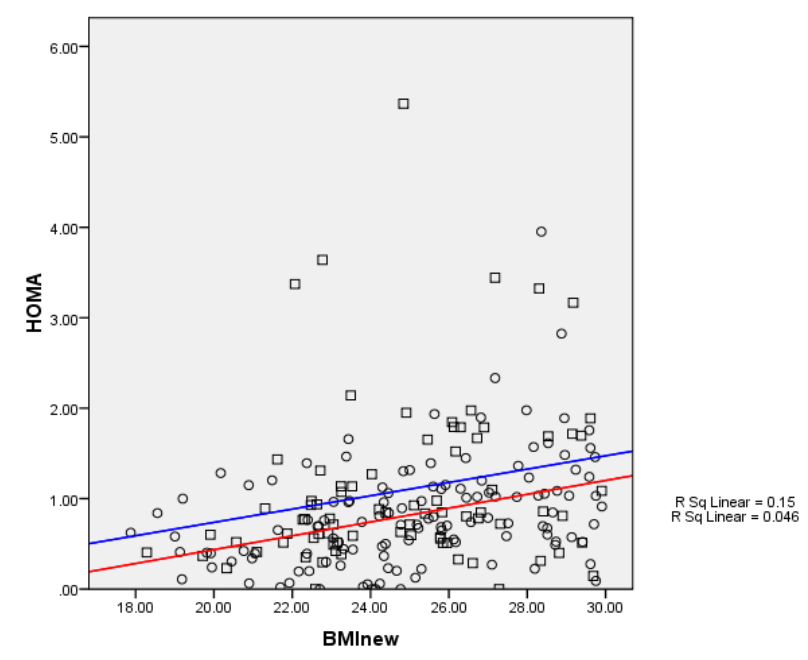

Fig (1): Correlation between HOMA and BMI. 


\section{Discussion}

Chronic hepatitis $\mathrm{C}$ is recognized as a global health problem, with 170 to 200 million people estimated to be infected worldwide. In the United States, chronic HCV is the most common cause of end-stage liver disease, hepatocellular cancer, and the most frequent indication for liver transplantation (Alter et al., 1999).In Egypt the situation is quite worse. Egypt contains the highest prevalence of hepatitis $\mathrm{C}$ in the world. The national prevalence rate of $\mathrm{HCV}$ antibody positivity has been estimated to be between 10-13\% (Mohamed MK, 2004). Type 2 diabetes (DM), obesity and hypertension (HTN) are associated with overall and liver related mortality in (HCV) infected patients. The top three predictors of liver related mortality were having higher body mass index (BMI), presence of insulin resistance (IR) and elevated serum cholesterol. Overall mortality in $\mathrm{HCV}$ patients was most linked to metabolic syndrome, higher BMI and hypertension (Rafiq, et al., 2009).

Our study was conducted on 277 patients with HCV and 867 healthy controls. We studied possible relationships between HCV morbidity and Insulin resistance (IR) detected by HOMA test in none diabetic and none obese patients.

Insulin resistance (IR) has been reported in $\mathrm{HCV}$-infected patients early in the course of $\mathrm{HCV}$ infection before the onset of cirrhosis (Caronia et al., 1999) (Mason et al., 1999) ( Eguchi et al., 2009).This agrees with the results of the current study as we found significant difference in HOMA score estimation between patients with $\mathrm{HCV}$ and controls with patients group having higher HOMA score (1.09203 \pm 0.925$)$ than control $(0.82783 \pm 0.598)$ with $(p<0.05)$ which is significant.We also found higher fasting insulin level in $\mathrm{HCV}$ patients than control with patients group having higher fasting insulin level (4.9098 \pm 3.8195$)$ than control (3.8708 \pm 2.6964) with $(p<0$. 05) which is significant. But no significant difference between patients $(81.6177 \pm 9.2598)$ and control (80.6306 \pm 9.3639$)$ as regard fasting glucose with (P>0.05) which is not significant.

Many studies proved that non diabetic HCVinfected patients have higher insulin resistance than patients with other chronic liver diseases
(Montasser et al., 2005) (Albert et al., 2006). Recently, it was demonstrated that in non diabetic $\mathrm{HCV}$ patients, the clearance of $\mathrm{HCV}$ after antiviral therapy induces an improvement in insulin resistance (RomeroGómez et al., 2003) (Kawaguchi et al., 2007). An improved glucose tolerance has been recognized following liver transplantation in HCV-positive diabetic patients, even without complete regression of IR (Tietge et al., 2004). These previous observations highlight the specific role of $\mathrm{HCV}$ in the evolution of impaired insulin action and impaired glucose tolerance, independent from the development of cirrhosis (Hui et al., 2003).Potential mechanisms for HCV induced IR was searched upon in many studies and showed decreased expressions of both IRS-1 and IRS2 in $\mathrm{HCV}$ core transfected human hepatoma cells and in the livers of HCV core transgenic mice and HCV-infected patients (Kawaguchi et al., 2004).Hepatic STAT-3 signaling recently has been shown to play a pivotal role in normal glucose homeostasis and insulin sensitivity and it was also observed that over expression of SOCS-1 and SOCS-3 proteins in obese animal livers enhanced SREBP-1c promoter activity by attenuating signal transducer and activator of transcription 3 (STAT-3)-mediated inhibition of this region. This process produced systemic IR and hepatic steatosis. These observations are relevant in the context of HCV infection, which has been recognized to influence the activity of STAT-3 (Ueki et al., 2004). Collectively, these data suggest that $\mathrm{HCV}$ per se is central to the development of IR (Ruan et al., 2003).

\section{Summary}

The study assessed HOMA-Score in the studied groups and shows that the test was significantly higher in the study group than the control group; denoting higher insulin resistance in the HCV study group than the control group.

\section{Conclusion}

- Chronic HCV is associated with significant insulin resistance.

- Insulin resistance is correlated significantly with higher liver enzymes. 


\section{Recommendations}

- Evaluation of insulin resistance on a large number of $\mathrm{HCV}$ patients in different stages of the disease (chronic, compensated cirrhosis and decompensated cirrhosis) is recommended.

- Study of the correlation between the HCV viral load and the degree of insulin resistance and its status after receiving pegylated interferon and ribavirin as a treatment for $\mathrm{HCV}$.

\section{References}

Abbott KC, Lentine KL, Bucci JR, Agodoa LY, Koff JM, Holtzmuller KC,Schnitzler MA(2004):Impact of diabetes and hepatitis after kidney transplantation on patients who are affected by hepatitis C virus. J Am Soc Nephrol15:3166 3174,2004.

Alberti A and Benvegnu L, (2003): Management of hepatitis C. Journal of hepatology;2003, 38: 104118.

Albert Lecube, Cristina Hernández, Joan Genescà, and Rafael Simó(2006):.Proinflammatory Cytokines, Insulin Resistance, and Insulin Secretion in Chronic Hepatitis C patients A case-control study .Diabetes Care 29:1096-1101, 2006.

Alter MJ, Kruszon-Moran D, Nainan OV, McQuillan GM, Gao F, Moyer LA, et al.(1999): The prevalence of hepatitis $\mathrm{C}$ virus infection in the United States, 1988 through 1994. N Engl J Med 1999;341(8):556-62.

Baid S, Cosimi AB, Farrell ML, Schoenfeld DA, Feng S, Chung RT, Tolkoff-RubinN, Pascual M(2001): Posttransplant diabetes mellitus in liver transplant recipients: risk factors, temporal relationship with hepatitis $\mathrm{C}$ virus allograft hepatitis, and impact on mortality. Transplantation72:1066-1072,2001.

Bigam DL, Pennington JJ, Carpentier A, Wanless IR, Hemming AW, et al (2000): Hepatitis C-related cirrhosis:a predictor of diabetes after liver transplantation. Hepatology32:87-90,2000.

Bonora $E$,Targher $G$ et al. (2000):Homeostasis model assessment closely mirrors the glucose clamp technique in the assessment of insulin sensitivity. Diabetes Care 2000; 23: 57-63.

Bonora E, Kiechl S, Willeit J, Oberhollenzer F, Egger G, Targher G et al.(1998): Prevalence of insulin resistance in metabolic disorders. The Bruneck Study. Diabetes 1998; 47:1643-1649.

Caronia S, Taylor K, Pagliaro L, et al.(1999): Further evidence for an association between non-insulin-dependent diabetes mellitus and chronic hepatitis $\mathrm{C}$ virus infection.Hepatology 1999;30:1059-63.

CDC (2009):Overweight and obesity web page, defining overweight and obesity, May 28, 2005.

Chieregatti G.(1999): The soluble sandwich approach for immunoassays, methodological and instrumental implications. Ann. Biol.Clin;48, 393397.

Cosio FG, Pesavento TE, Osei K, Henry ML, Ferguson RM(2001): Post-transplant diabetes mellitus: increasing incidence in renal allograft recipients transplanted in recent years.Kidney Int59 :732-737,2001.

Emoto M, Nishizawa Y, Maekawa K, Hiura Y, Kanda H, Kawagishi T et al(1999):Homeostasis model assessment as a clinical index of insulin resistance in type 2 diabetic patients treated with sulfonylureas. Diabetes Care 1999; 22: 818-822.

Garrido Serrano A, Guerrero Igea FJ, Lepe Jiménez JA, Palomo Gil S, Grilo Reina(2001): Hyperinsulinemia in cirrhotic patients infected with hepatitis C virus infection. Gastroenterol Hepatol24 :127-131,2001.

Haffner SM(1997):The prediabetic problem: Development of non insulindependent diabetes mellitus and related abnormalities. J Diabetes Complications 11:69-76, 1997.

Haffner SM, Miettinen H(1997):Insulin resistance implications for type II diabetes mellitus and coronary heart disease. Am J Med 103:152-162, 1997.

Hui JM, Sud A, Farrell GC, et al.(2003):Insulin resistance is associated with chronic hepatitis $\mathrm{C}$ virus infection and fibrosis progression. Gastroenterology 2003;125:1695-704.

Hunter SJ, Garvey WT (1998):Insulin action and insulin resistance: Diseases involving defects in insulin receptors, signal transduction, and the glucose transport effector system. Am J Med 105:331-345, 1998.

Jee-Fu Huang, Chia-Yen Dai, Shang-Jyh Hwang and Chi-Kung Ho et al(2007):Hepatitis C viremia increases the association with type 2 diabetes mellitus in hepatitis $\mathrm{B}$ and $\mathrm{C}$ endemic area: an epidemiological link with virological implication.Am J Gastroenterol. 2007 Jun; 102 (6):1237-43

Kasiske BL, Snyder JJ, Gilbertson D, Matas $A J(2003)$ :Diabetes mellitus after kidney transplantation in the United States. Am J Tranplant3 $: 178-185,2003$.

Kawaguchi T, Yoshida T, Harada M, et al.(2004):Hepatitis $C$ virus down-regulates insulin receptor substrates 1 and 2 through up-regulation of suppressor of cytokine signaling 3. Am J Pathol 2004; 165: 1499-508.

Kawaguchi T, Ide T, Taniguchi E, Hirano E, Itou $M$, Sumie S, Nagao Y, Yanagimoto C, Hanada S, Koga H, Sata M.(2007):Clearance of HCV 
improves insulin resistance, Betacell function, and hepatic expression of insulin receptor substrate 1 and 2.Am J Gastroenterol. 2007 Mar;102(3):570-6. Lecube A, Hernandez, C, Genesca J, Esteban JI, Jardi R, Garcia L, Simo R(2004):Diabetes is the main factor accounting for the high ferritin levels detected in chronic hepatitis $\mathrm{C}$ virus infection. Diabetes Care27 :2669 -2675,2004.

Leinonen $M$ and Saikku $P$ (2002): Evidence for infectious agents in cardiovascular disease and atherosclerosis. Lancet Infect Dis 2002; 2(1):11-7. Mangia A, Schiavone G, Lezzi G, Marmo R, Bruno F, Villani MR, Cascavilla I,Fantasia L, Andriulli A(1998): $\mathrm{HCV}$ and diabetes mellitus: evidence for a negative association. Am $\mathbf{J}$ Gastroenterol93 :2363-2367,1998.

Mason AL, Lau JYN, Hoang $N$ et al.(1999):Association of diabetes mellitus and chronic hepatitis $\mathrm{C}$ virus infection. Hepatology 1999; 29: 328-33.

Matthews DR, Hosker JP, Rudenski AS, Naylor BA, Treacher DF, Turner RC(1985): Homeostasis model assessment: insulin resistance and beta-cell function from fasting plasma glucose and insulin concentrations in man. Diabetologia 1985; 28: 412-419.

Mohamed MK.(2004):Epidemiology of HCV in Egypt 2004. The Afro-Arab Liver Journal, 2004; 3:2, 41-52.

Montasser M.F.,Mansour M.A.,El-Rassed M.M.,Mahmoud H.M.(2005): Prevalence of insulin resistance in non diabetic $\mathrm{HCV}$ patients.(2005) thesis.Tropical department faculty of medicine -Ain Shams university.

Opara JU, Levine JH(1997): The deadly quartet: The insulin resistance syndrome. South Med J 90:1162-1168, 1997.

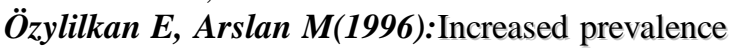
of diabetes mellitus in patients with chronic hepatitis C virus infection. Am J Gastroenterol 91 :1480-1481,1996

Parolin MB, Zaina FE, Araujo MV, Kupka E, Coelho JC.(2004):Prevalence of type 2diabetes mellitus in Brazilian liver transplant candidates: negative association withHCV status. Transplant Proc 2004;36 :2774 -2775,

Romero-Gomez M, Castellano-Megias VM, Grande L, et al.(2003):Serum leptin levels correlate with hepatic steatosis in chronic hepatitis C. Am J Gastroenterol 2003;98:1135-41.
Ruan H, Lodish HF.(2003): Insulin resistance in adipose tissue: direct and indirect effects of tumor necrosis factor- . Cytokine Growth Factor Rev 2003; 14:447-55.

Sihoon Lee, Sunghee Choi, Hae Jin Kim, Yoon Sok Chung, Kwan Woo Lee, Hyun Chul Lee, Kap Bum Huh, Dae Jung Kim(2006): .Cutoff Values of Surrogate Measures of Insulin Resistance for Metabolic Syndrome in Korean Non-diabetic Adults. J Korean Med Sci. 2006 Aug; 21(4):695700.

Strickland GT, Elhefni H, Salman T, et al (2002): Role of hepatitis $\mathrm{C}$ infection in chronic liver disease in Egypt. Am J Trop Med Hyg.;2002,67(4):436-42.

Taniguchi A, Fukushima M, Sakai M, Kataoka K, Nagata I, Doi K et al(2000): The role of the body mass index and triglyceride levels in identifying insulin-sensitive and insulinresistant variants in Japanese non-insulin-dependent diabetic patients. Metabolism 2000; 49: 1001-1005.

Thuluvath PJ, John PR.(2003):Association between hepatitis $\mathrm{C}$, diabetes mellitus, and race:a case-control study. Am J Gastroenterol98:438 $441,2003$.

Tietge UJ, Selberg $O$, Kreter A, et al(2004): Alterations in glucose metabolism associated with liver cirrhosis persist in the clinically stable long-term course after liver transplantation. Liver Transpl 2004;10:1030-40.

Ueki K, Kondo T, Kahn CR.(2004):Suppressor of cytokine signaling 1 (SOCS-1) and SOCS-3 cause insulin resistance through inhibition of tyrosine phosphorylation of insulin receptor substrate proteins by discrete mechanisms. Mol Cell Biol 2004;24:5434-46.

WHO (2004): Noncommunicable diseases: risk factors and regional strategies for prevention and care. Eastern Mediterranean, 10 (6) 2004, 778 788.

Yildiz A, Tütüncu Y, Yazici H, Acalla V, Kayacan SM, Sever MS, Carin M,Karsidag K(2002): Association between hepatitis C virus infection and development of posttransplantation diabetes mellitus in renal transplant recipients. Transplantation 2002;74:1109-1113.

Zein NN, Abdulkarim AS, Wiesner RH, Egan KS, Persing DH(2000):Prevalence of diabetes mellitus in patients with end-stage liver cirrhosis due to hepatitis C, alcohol,or cholestatic disease. J Hepatol 2000;32:209-217. 


\title{
العلاقة بين الأصابة بفيروس الإلتهاب الكبدي المزمن "سي" وحدوث مقاومة لتأثير الأسولين في المرضى الغير مصابين بالسمنة ومرض الإبري السكر
}

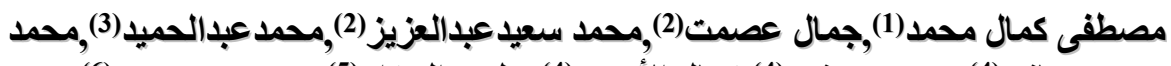

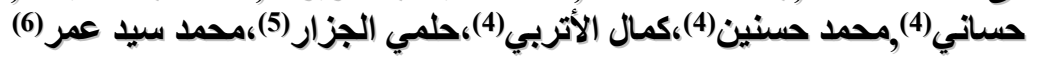 \\ 1-قسم الصحة العامة ـكلية الطب - جامعة عين شمس. \\ 2-قسم الأمر اض المتوطنة_ كلية طب قصر العبنة العيني-جامعة القاهرة.

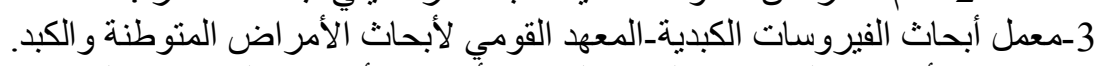

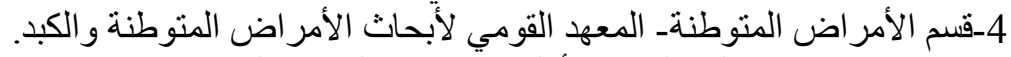

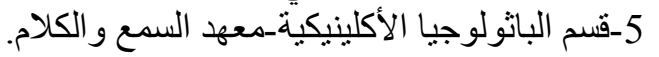

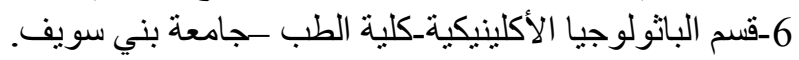

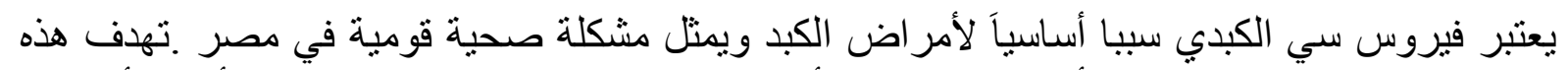

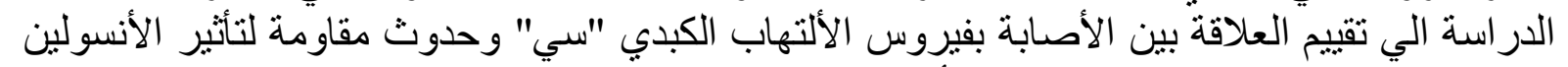

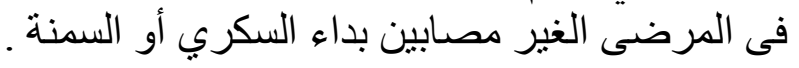

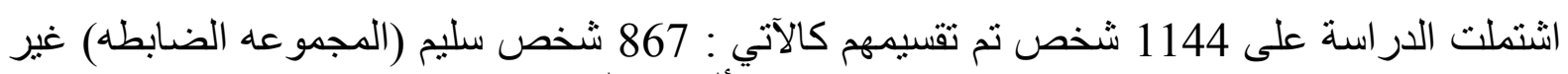
مصاب بفيروس سي و 277 مريض مصاب بفيروس الألتهاب الكبدي سي.

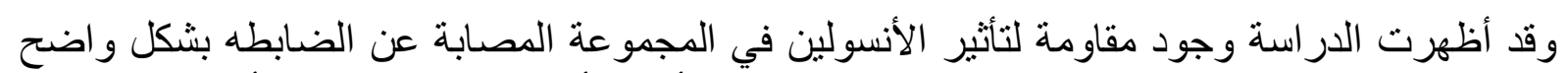

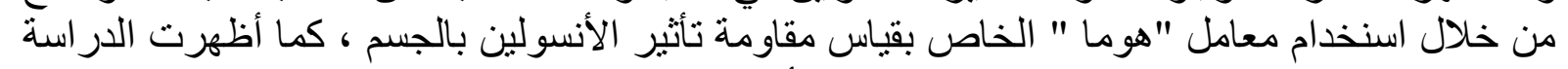

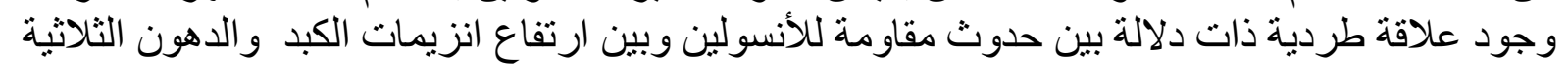

